\title{
The Spearing Tool Filing System Disaster
}

\author{
LYNN M. LOPUCKI*
}

Debtor name errors have been a substantial and persistent problem for filers and searchers in the Uniform Commercial Code Article 9 filing system. Filers make errors in spelling, punctuation, and spacing; use trade names; and include extraneous words. The law prior to 2001 excused such errors if they were "minor" and "not seriously misleading." That put the burden on searchers to conduct "reasonably diligent searches" to find erroneous filings. The effect was to render all searches problematic and costly.

The drafters of revised Article 9 conceived a brilliant solution to the problem with respect to corporate debtors ("registered entities"). First, they required that filings be in the exact, correct names of debtors, forgiving only errors that would be caught by the filing office's official search logic. That meant a searcher could conduct a single search in the exact, correct name of a debtor and be assured of finding every effective filing. Second, to make filing in the exact, correct name easy, the drafters changed the place for filing against a corporate debtor to its state of incorporation. With possession of both the corporate records that contained the exact, correct name of an entity and the right to receive all Article 9 filings against that entity, each state's administrator could set up a system in which filers and searchers picked their targets from lists of all entities incorporated in the state rather than attempting to correctly reproduce their target's name. Those "point-and-click" systems would have completely eliminated debtor name errors.

Before the administrators could act, the Sixth Circuit, in Spearing Tool, held a federal tax lien filing valid despite the Internal Revenue Service's failure to comply with the exact, correct name requirement. The practical effect of the decision was to reinstate the "reasonably diligent search" requirement for Article 9 searching, make point-and-click systems impossible, and so nullify the drafters' efforts-leaving an estimated thirty percent of filings invalid. This Essay applies systems analysis to demonstrate that Spearing Tool imposed catastrophic system costs while yielding no significant benefits.

\section{INTRODUCTION}

Errors in debtors' names have plagued the Article 9 filing system since its inception. Courts, scholars, and committees have written thousands of pages

Security Pacific Bank Professor of Law, UCLA Law School. lopucki@law.ucla.edu. I thank Carl R. Ernst, Bill Warren, and Steve Weise for comments on earlier drafts. 
on the topic ${ }^{1}$ and law professors teach debtor name errors as a standard part of a secured transaction course. ${ }^{2}$

Over the past fifteen years, legal scholars, Article 9 drafters, and state filing officers designed and partly implemented a system that would have permanently and completely solved the debtor-name problem with respect to corporate debtors. ${ }^{3}$ Had the project gone to completion, corporate debtor-name-errors (as opposed to mistaken identities) would have been physically impossible, periodic searching would have been unnecessary, and a solution to the individual-debtor name problem might have been within reach. 4

In June, 2005, as the debtor-name-error elimination project stood on the brink of success, the Sixth Circuit issued its opinion in Spearing Tool. ${ }^{5}$ The

${ }^{1}$ See, e.g., the reported opinions that are collected at Donald J. Rapson, UCC CASE DIG. I 9402.6 (2004) (listing dozens of debtor name error cases). The Article 9 study group considered the debtor name problem sufficiently serious to suggest "indexing financing statements according to numbers (i.e., social security or tax I.D. numbers), either in addition to or instead of names." PERMANENT EDITORIAL BOARD FOR THE UNIFORM

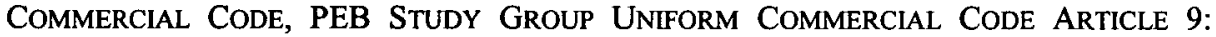
REPORT 89 (1992). E.g., Paul J. Ricotta \& Adrienne K. Walker, What's in a Name? (Apparently a Lot), 26 AM. BANKR. INST. J., May 2005, at 26; John K. Pearson, Search Logic from MARS, 21 AM. BANKR. INST. J., May 2002, at 24; G. Ray Warner, Using the Strong-Arm Power to Attack Name Errors Under Revised Article 9, 20 AM. BANKR. INST. J., Oct. 2001, at 22; Julianna Zekan, The Name Game-Playing to Win Under $\$ 9-402$ of the Uniform Commercial Code, 19 HofSTRA L. REV. 365 (1990); Todd D. Penney, Article 9 Financing Statement Searches: Is a Rose by Any Other Name Still a Rose?, 51 OHIO ST. L.J. 1415 (1990).

2 See, e.g., LYNN M. LOPUCKI \& ElIZABETH WARREN, SECURED CREDIT: A SYSTEMS APPROACH 294-306 (5th ed. 2006) (debtor name requirement); RANDAL C. PICKER ET AL., SECURITY INTERESTS IN PERSONAL PROPERTY 105-15 (3d ed. 2002) (debtor name ertor problem); John O. HoNnOld, STEVEN L. HARRIS \& ChARLES W. MOONEY, JR., SECURTTY INTERESTS IN PERSONAL PROPERTY 162-65 (3d ed. 2001) (debtor name requirement); William D. Warren \& Steven D. Walt, Secured Transactions in Personal PROPERTY 66-71 (6th ed. 2004) (stating that the "correct name" of a corporate debtor "is available by computer search").

${ }^{3}$ Unless otherwise indicated, "corporate debtor" and "corporation" are used in this Article in the broad sense to include all "registered organizations" as that phrase is used in the Uniform Commercial Code. U.C.C. § 9-102(a)(70) (2004) (defining "registered organization"). Thus, "corporations" include limited partnerships, limited liability companies, and similar entities.

${ }^{4}$ E.g., Lynn M. LoPucki, Why the Debtor's State of Incorporation Should Be the Proper Place for Article 9 Filing: A Systems Analysis, 79 MINN. L. REV. 577, 603-04 (1995) ("Although error trapping could not eliminate errors in which the filer mistakes one corporation for another, it could eliminate filings on which the name does not match the name of any corporation formed in the state.").

5 United States v. Crestmark Bank (In re Spearing Tool and Mfg. Co., Inc.) (Spearing 
effect of that decision was to wipe out most of the progress made, leave an estimated thirty percent of security interests granted by registered organizations unperfected and so avoidable by the organizations' trustees in bankruptcy, and make continuation of the project nearly impossible.

The function of the Article 9 filing system is to provide notice of prior security interests to those who consider taking subsequent ones (hereafter "searchers"). The holder of the prior interest gives notice by filing a "financing statement" in the Article 9 filing system. The searcher discovers the prior interest by searching in that system. Generally, the search is by debtor name. ${ }^{6}$ If the debtor's name is spelled incorrectly in either the financing statement or the search request, the communication can fail, leaving both filer and searcher with the belief that its interest has priority.

Spelling a corporate debtor's name correctly can be a formidable task. Debtors use "trade names" without designating them as such; misspell their own corporate names on letterhead, checks, and in directories; ${ }^{7}$ and exchange abbreviations for the words abbreviated at will. With the advent of computerized searching, even tiny differences in spelling, ${ }^{8}$ punctuation, ${ }^{9}$ spacing, or abbreviation ${ }^{10}$ can be enough to cause communication through the filing system to fail. Including words in the debtor name space on the form that are not in fact part of the debtor name - such as "a corporation" or "a partnership"-can do the same.

The correct spelling of a corporate name appears in the corporate records of the state of incorporation. But before the internet, checking those records

Tool III), 412 F.3d 653 (6th Cir. 2005), reh'g denied, 2005 U.S. App. LEXIS 29219.

${ }^{6}$ E.g. Nevada U.C.C. Login Page, https://esos.state.nv.us/NVUCC/ucc/ucc11/html/Default.asp (last visited Jan. 27, 2007) (Nevada official website permitting searches only by debtor name); Edward S. Adams \& Steve H. Nickles, Amending the Article Nine Filing System to Meet Current Deficiencies, 59 Mo. L. REV. 833, 840 (1994) ("Because financing statements are indexed alphabetically according to the name of the debtor, the debtor's name as written becomes the only means by which a particular financing statement may be located.").

${ }^{7}$ E.g., Transamerica Commercial Fin. Corp. v. Gen. Elec. Capital Corp. (In re Wardcorp, Inc.), 133 B.R. 210, 211 (Bankr. S.D. Ind. 1990) ("Some of the Debtor's checks have its correct name, but others bear the name Ward Corp, Inc., as does an insurance policy. A 1985 balance sheet names the Debtor as Ward Corporation.").

${ }^{8}$ In re Tyler, 23 B.R. 806, 809-10 (Bankr. S.D. Fla. 1982) (filing held ineffective because debtor's correct name, "Tri State Moulded Plastics, Inc.," was misspelled "Tri State Molded Plastics, Inc.").

${ }^{9}$ ITT Commercial Fin. v. Bank of the West, 166 F.3d 295, 304-05 (1999) (filing held ineffective because debtor's correct name, "Compu-Centro, USA, Inc." was misspelled "Compucentro, USA, Inc.").

${ }^{10}$ Transamerica Commercial Fin., 133 B.R. at 215 (filing held ineffective because debtor's correct name, "Wardcorp, Inc." was misstated "Ward Corporation, Inc."). 
took days, or in some cases, weeks. ${ }^{11}$ Few filers or searchers used them. As a result, debtor name errors on filings were common.

Most debtor-name-errors in filings or search requests could be, and were, overcome in the search process. Precisely which errors could be overcome depended upon the nature of the error and the method by which searches were conducted in the particular filing system. For example, if a filing misspelled "Tri State Moulded Plastics" as "Tri State Molded Plastics" and the search was conducted on a printed list of filings that were in alphabetical order by debtor's name, the searcher would almost certainly notice the misspelling and realize what it was. For that reason, former Article 9 instructed the courts to ignore debtor name errors in financing statements if they were "minor" and "not seriously misleading." 12 To implement that standard, the courts developed the "reasonably diligent search" test. ${ }^{13}$ If a reasonably diligent search would discover the erroneous filing, the filing was effective despite the error.

The practical effect of the reasonably diligent search test was to render the search process burdensome and uncertain. Numerous opinions made clear that the reasonably diligent searcher searched not only for the name of its debtor, but also for misspellings and variations of that name ${ }^{14}$ - how, how many, or how egregious, no one could say. Searchers who did less risked subordination. The search process ballooned. In 1995, one study placed the typical fee attributable to filing system costs for loans at more than $\$ 25,000$ for loans that centered in the range of $\$ 20$ million to $\$ 74$ million. ${ }^{15}$ Under the reasonably diligent search test, even those expenditures could not buy peace of mind.

Most searchers did not do reasonably diligent searches. ${ }^{16}$ They searched

11 Some states required that a request to search the corporate records be in writing, accompanied by a check for payment of the search fee.

12 U.C.C. $\$ 9-402(8)(1972)$.

${ }^{13}$ E.g., In re Summit Staffing of Polk County, Inc., 305 B.R. 347, 354 (Bankr. M.D. Fla. 2003) ("Courts applying former Article 9 imposed a duty on searchers to be reasonably diligent.").

${ }^{14}$ E.g., Citizens Nat'l Bank \& Trust Co. v. Star Auto. Warehouse (In re Thriftway Auto Supply), 25 U.C.C. Rep. Serv. 2d 982, 986 (10th Cir. 1994) ("A reasonably prudent creditor conducting a reasonably diligent search would have formulated a search aimed at revealing filings under substantially similar names.").

15 Peter A. Alces, Abolish the Article 9 Filing System, 79 MINN. L. REV. 679, 691 (1995) (reporting a study by attorney Meredith Jackson of one hundred billings by Bingham, Dana \& Gould).

16 For example, the Indiana Secretary of State advised searchers that "the only certainty [in searching] is that a party will get filings under the exact name and spelling given [on the search request], assuming no error by the clerk." Transamerica Commercial 
in what they thought to be the name of the debtor, and-knowingly or unknowingly-assumed the risk of erroneous but effective filings. ${ }^{17} \mathrm{~A}$ whole new industry sprang up to insure that risk. ${ }^{18}$ The filing system was failing.

In the mid-1990s, the drafters of revised Article 9 conceived a brilliant solution to the debtor-name-error problem: make exact, correct names easily available to filers and searchers, initially require that they use them, and ultimately make it impossible not to use them. When promulgated in 1998, revised Article 9 required filing in the exact, correct name of the debtortolerating only errors that the filing office's search logic would overcome. The new rule eliminated the necessity for a reasonably diligent search. As Professor G. Ray Warner described the change:

Under prior law, the courts determined whether an error was seriously misleading by asking whether a hypothetical "reasonably diligent searcher" could discover the erroneous filing. Under this standard, human judgment was relevant, and being close was often good enough. For name errors, the revision replaces this reasonableness standard with a precise standard based on the computerized search logic used by the relevant filing office. Under the new standard, a name error is fatal if a search under the correct name, using the filing office's standard search logic, would not disclose the financing statement. ${ }^{19}$

As a result of the change, a single search in the exact, correct name of the corporate debtor would find all effective Article 9 financing statements.

To reap the benefits of the new system, the searcher had to know their debtor's exact, correct name. To give filers and searchers easy access to those names, the drafters changed the place for filing from the location of the collateral or the debtor to the debtor's state of incorporation. ${ }^{20}$ That change put the public record showing the debtor's exact, correct name in the hands of the filing officer who would receive filings and search requests regarding that

Fin. Corp. v. Gen. Elec. Capital Corp. (In re Wardcorp, Inc.), 133 B.R. 210, 212 (Bankr. S.D. Ind. 1990). Despite that admonition, the Indiana filing office reported that "not many search requests ask[ed] for [searches under] name variations." Id.

17 Id.

18 The main page of the UCC Plus website states that the company "Insures Commercial Loans Secured By Non-Real Estate Assets For . . Perfection and Priority." UCCPlus.com, http://www.uccplus.com (last visited Jan. 27, 2007). The main page of its competitor, First American's EAGLE 9 UCC Division states that it provides " [i]]nsur[ance of] the attachment, perfection and priority of a lender's security interest in the personal property collateral of the debtor." Eagle9.com, http://www.eagle9.com (last visited Jan. 27, 2007).

19 Warner, supra note 1 , at 22.

${ }^{20}$ U.C.C. $\S \S 9-301(1), 9-307$ (e) (2001). 
debtor. Harry Sigman, a member of the Revised Article 9 Drafting Committee, noted the relationship between the two changes:

In the case of a registered organization, the debtor's name is the name as shown on the public records of the jurisdiction that shows the debtor to have been organized there. The provision enables filers and searchers to rely with certainty on the debtor's exact name obtained from an objective and publicly available source.... It also dovetails with the new rule for proper place to file....21

To completely eliminate spelling errors in filing and searching, only one further step was needed. The filing officers had to construct on-line filing and search systems that would display the exact, correct names of the state's corporations and require filers and searchers to identify their debtors by choosing among them-a system known as "point-and-click."22

In that new system, searchers would no longer have had to master reasonably diligent search case law or filing office search logic, examine debtors' patterns of name use, collect "tips" regarding name variations, search in name variations, or struggle to eliminate errors in data entry. Filers and searchers would have had only to look at the corporate information on-line and click on the name of the right corporation.

All fifty states adopted revised Article 9 . In the large majority of them, the new law took effect July 1, 2001. State filing officers began the slow, costly process of revising their computer systems to implement these features of the new law. By the time the Spearing Tool disaster struck in June 2005, most filing officers had systems that displayed exact, correct names on-line and a few had point-and-click systems that integrated those exact, correct names into their on-line filing and search systems.

Spearing Tool eviscerated the name-error elimination project by holding a notice of tax lien filed in the Article 9 filing system to be effective, even though it did not comply with Article 9's exact, correct name requirement. Part of the court's rationale was that the notice filed could have been found by a reasonably diligent search.

The decision applied only to tax liens, not to Article 9 filings. But in most states, tax liens and Article 9 filings are mixed together in the same index. The searcher simultaneously searches for both. That simultaneous search must

21 Harry C. Sigman, The Filing System Under Revised Article 9, 73 AM. BANKR. L.J. 61,72 (1999).

22 LoPucki, supra note 4, at 619 n.138 ("The computer program that facilitates electronic filing might offer a 'point-and-click' feature in which the user has access to a list of all entities registered in the state, places the cursor on the one it wishes to file against, and 'clicks' on it."). 
include the steps necessary to find tax liens as well as the steps necessary to find Article 9 filings. Thus, by imposing the reasonably diligent search requirement on those searching for tax liens, Spearing Tool imposed it on all searchers. The effect was to resurrect the reasonably diligent search requirement for Article 9 searching. ${ }^{23}$

Even though Spearing Tool eliminated the reform's search benefits for most searchers, it left the exact, correct name requirement in place for filers other than the IRS. That requirement no longer serves its original purpose of easing the burden on searchers. But it continues to invalidate filings with minor errors that harm no one because they would be found in the reasonably diligent searches now required. That system malfunction now invites half-a-loaf reform that will permanently prevent elimination of the debtor-name-error problem.

Part II of this Essay describes the function of the Article 9 filing system, explains the role of corporate names within it, and explains how the name-error reforms were supposed to work. Part III describes the Spearing Tool litigation. Part IV provides a strategic analysis of the effect of the Spearing Tool decision on the Article 9 filing and search system. (Strategic analysis considers what participants are likely to do in response to changes in the functioning of a law-related system.) Part IV also demonstrates that no law required the court to decide Spearing Tool as it did. Part V considers how incremental reform might go forward in the wake of Spearing Tool and concludes that it cannot. That Part also sets forth a proposal for a compact between the Article 9 drafters and the Internal Revenue Service that would mandate the debtor-name-error elimination project. Part VI concludes that after Spearing Tool, such a compact is the only means by which the debtor-name-error elimination project can be resuscitated.

\section{The FILING SySTEM's PROGRESS}

The function of the Article 9 filing system is to communicate the existence $\longrightarrow$ or the absence - of prior liens to future lenders so that those future

23 Dennis H. Long, Searching for Federal Tax Liens: The Typical Search for UCC Financing Statements May Not Be Good Enough, 23 AM. BANKR. INST. J., Oct. 2004, at 64 ("Although [the bankruptcy court's decision in Spearing Tool] was reversed by the district court, the issue remains unresolved in most jurisdictions. Prudence would dictate a more extensive search using variations of the correct name."). Financing Statements, CoM. LENDING LITIG. NEWS, July 21, 2005 ("Although the court limited its decision [in Spearing Tool] to the specific facts of the case, the decision suggests that creditors operating in the 6th Circuit will have to search variations of a debtor's name in order to detect preexisting tax liens ...."). 
lenders can fix accordingly the terms on which they will offer credit. ${ }^{24}$ To illustrate this function, consider the situation of a Bank that contemplates lending to a Corporation against certain Machinery. On its loan application, the Corporation represents that the Machinery is free and clear of liens. Bank can investigate the truth of that representation by searching for prior liens. Bank's principal means for doing so is to search the Article 9 filing system. If that search discovers a lien in favor of PriorBank, Bank can refuse to make the loan it now contemplates or can make the loan on different terms.

The filing system is composed of four processes (subsystems): (1) filing, (2) indexing, (3) search requesting, and (4) search execution. In the filing process, lien holders file notices of their liens-typically in the form of "financing statements." Each financing statement identifies the debtor, the lienor, and the collateral. ${ }^{25}$ The lienors file financing statements because if they do not, the law subordinates their liens. ${ }^{26}$

The filing office "indexes" the financing statement by creating a separate record that contains at least the debtor's name, address, and the file number of the financing statement. Searches are conducted by debtor name in the index. Official search requests are made by delivering to the filing officer a record that identifies the debtor by name or a financing statement by number. The searcher typically submits the search request by mail, by hand delivery through a service company, or, increasingly, by filling out a form on the filing office website. The filing officer executes the search by comparing the debtor's name on a search request to the debtors' names in the index. The filing officer then furnishes a search report to the searcher. ${ }^{27}$ The report lists the file numbers of the filings that match the search request.

\section{A. The Name-Error Problem}

To uniquely identify a corporation requires not only the exact, correct name of the corporation, but also the corporation's jurisdiction of incorporation. That is, each registered organization is organized under the law of a state government or the federal government, and that government maintains a record of its existence. ${ }^{28}$ Each of those governments permits only

24 Ricotta \& Walker, supra note 1, at 26 ("The purpose of a financing statement is to give third parties notice of the potential existence of a security interest in personal property.").

25 U.C.C. $\S 9-502$ (a) (2001).

26 U.C.C. $\$ \S 9-303,9-310,9-322$ (a) (2001); 11 U.S.C. $\$ 544(a)$ (2000). LOPUCKI \& WARREN, supra note 2, at 479 (explaining the language of 11 U.S.C. $\S 544(a)$ ).

27 U.C.C. $\S 9-523(c)$.

28 U.C.C. § 9-102(a)(70) (defining "registered organization"). 
one corporation to have any particular name. If, for example, the state of Ohio has already chartered a corporation by the name "Magnetics Corporation," that state will not incorporate another. California may charter another "Magnetics Corporation." But even if it does, the designation "Magnetics Corporation [the exact, correct name], an Ohio corporation [the jurisdiction of organization]" still distinguishes the two. Thus, if (1) all filers file in the exact, correct names of their corporate debtors, (2) all searchers search in the exact, correct names, and (3) both include their debtors' jurisdictions of incorporation, the computer can make perfect matches. Article 9 searching becomes a trivial task.

The name-error problem arises from the fact that many do not search or file in their debtor's exact, correct names. A corporate debtor's exact, correct name appears on the records of the state that incorporated the debtor, so filers and searchers could consult the record and obtain the exact, correct name. But many do not do so and instead proceed using an erroneous name. Even those that do consult the record may commit transcription errors in spacing, punctuation, and spelling.

The number of errors is astonishingly high. In a detailed examination of filings against registered organizations in the State of Vermont, Carl Ernst found that sixty-three percent of filers entered names that were not exact, correct matches to the names of those registered organizations on Vermont's corporate records. ${ }^{29}$ Even assuming a search logic that ignores punctuation, spaces, entity endings, and some noise words, thirty percent of the names still did not match any name on the registered organization index. ${ }^{30}$ Ernst reports that his firm's "experience in analyzing debtor name errors in other states leads us to think that these figures are roughly applicable in any state." 31 Thus, it appears that thirty percent of Article 9 filings against registered organizations are ineffective, leaving the creditors, for all practical purposes, unsecured.

Given the severity of the consequence for the filer-loss of priority on a loan that may be millions of dollars--the refusal to forgive even the smallest of these errors seems entirely unreasonable. At the same time, forgiving any error the filing officer search logic will not catch imposes a similarly unreasonable burden on searchers. It compels searchers to find even erroneous filings, under penalty of subordination of their own loans. In addition, in searching for erroneous filings against their debtors, searchers inevitably discover filings against other debtors with similar names and must spend additional effort sorting out these false positives. The aggregate costs of

${ }^{29}$ Carl Ernst, Compliance with Rev. UCC \$ 9-503, 506(b) in Vermont: A Technical Report, part 6 (forthcoming 2007) (on file with the author).

${ }^{30} \mathrm{ld}$.

${ }^{31} \mathrm{Id}$. 
operating the system mount.

\section{B. Solution to the Name-Error Problem Under Former Article 9}

Prior to the 1998 revision of the official text of Article 9, U.C.C. section 9-402 provided in relevant part that: "A financing statement sufficiently shows the name of the debtor if it gives the . . corporate name of the debtor.... A financing statement substantially complying with the requirements of this section is effective even though it contains minor errors which are not seriously misleading." 32

In context, the effect of this provision was to render a financing statement with the debtor's name spelled incorrectly effective, provided that the error was "minor" and "not seriously misleading." Because such a financing statement was effective to confer priority on the filer, the searcher had to search in a manner that would find it or risk loss of priority.

The searcher's ability to find an erroneous filing differed widely from state to state because of differences in the physical systems for requesting and executing searches. In some systems, the filing officer made public an index of effective filings, listed alphabetically by debtor's name. In those systems, the hard-copy printout of the index resembled a big-city telephone directory. By scanning the relevant area of that alphabetical printout, a searcher could overcome a wide variety of spelling errors. For example, simply by looking at the part of the list where "Magnetics Corporation" should be, the searcher would find filings against "Magnefics Corporation," "MagneticsCorporation," "Magnetics Corp.," or "Magnetics, Inc." Other systems did not permit the searcher to scan the index, but did allow the searcher to sit at a computer terminal, enter word searches, and modify the search depending on the results. By using "wild card" characters in their searches, the searchers could overcome an even wider variety of spelling errors.

In yet other systems, searchers had no direct access to the official index at all. All a searcher could do was to submit a name to be searched, and receive a list of filings said to match. If the searcher wanted to search under variants of a name - either because the searcher was uncertain of the debtor's exact, correct name or because the searcher feared an effective filing in an erroneous name - the searcher had to submit each variant and pay a fee for its search. ${ }^{33}$

To complicate matters further, in the 1980s many filing officers began selling copies of their databases to private companies. The private companies

32 U.C.C. § 9-402(8) (1978).

33 See Transamerica Commercial Fin. Corp. v. Gen. Elec. Capital Corp. (In re Wardcorp, Inc.), 133 B.R. 210, 212 (Bankr. S.D. Ind. 1990) (describing the Indiana search system, which put the burden on searchers to request searches in name variations). 
provide or permit the use of search engines that employ search parameters and logic different from that of the filing office. The existence of these private databases made it possible for "unofficial" searches to find filings that "official" searches would not.

While former Article 9 remained in effect, the courts were repeatedly forced to determine whether particular kinds of debtor-name errors in financing statements were "seriously misleading." By 1998, the courts had largely reached agreement. An error that would have prevented a reasonably diligent searcher from finding the filing made the filing seriously misleading. Other errors did not. ${ }^{34}$

That conclusion alone, however, largely begged the question. A sufficiently thorough search could overcome virtually any debtor's name-error. ${ }^{35}$ The reasonably diligent searcher might, for example, visit the debtor's business premises to discover trade names or guess likely misspellings of the debtor's corporate name and search under them. Searching in a private copy of the database might discover filings that would not show up on an official search. The issue was how far the searcher had to go to be reasonably diligent. The standard made clear that a few kinds of extremely expensive search methods were not required. ${ }^{36}$ But over a wide range of possibilities, the logic was circular. One could not know whether a filing was effective until one knew what a reasonably diligent searcher would do. But because a reasonably diligent searcher contemplating a large enough loan would do whatever was necessary to find a filing that was effective, one could not know what a reasonably diligent searcher would do until one first knew what filings were effective.

Prior to the 1998 revision, scholars had reached a consensus that the Article 9 filing system was unreasonably expensive and difficult to use. ${ }^{37}$

34 E.g., id. at 213.

35 To take the extreme case, assume that a filing against Magnetics Corporation incorrectly lists the debtor's name as "Able Plumbing and Electrical Co.," a name in no way related to Magnetics Corporation. A searcher could overcome the error by obtaining a copy of every financing statement on file against any corporation-including the Able Plumbing and Electrical Co. filing - calling the secured creditors who made each of those filings, and asking whether they are lenders to Magnetics Corporation. Of course, such a search would be prohibitively expensive.

36 For example, the searcher would not be required to contact everyone who filed an Article 9 financing statement to ask whether the debtors' names listed in those statements were incorrect. See supra note 35.

${ }^{37}$ E.g., Alces, supra note 15 , at 680 ("Perversely, the present filing system makes it easy to stake a claim, but makes verification expensive and uncertain."); Adams \& Nickles, supra note 6, at 834 (referring to the "notice-filing system" as "in serious need of repair"); Steven L. Harris \& Charles W. Mooney, Jr., Choosing the Law Governing Perfection: The 
Courts had made numerous decisions validating filings that could not be found by a search in the correct name of the debtor. Searching in name variations seemed to be required, but few searchers were doing them. Bankruptcy courts were avoiding large numbers of filings for name-errors.

\section{Solution to the Name-Error Problem Under Revised Article 9}

Revised Article 9 introduced bold changes designed to streamline the process for filing and searching. First, it limited effective filings to those made in the exact, correct name of a corporate debtor: "A financing statement sufficiently provides the name of the debtor, (1) if the debtor is a registered organization, only if the financing statement provides the name of the debtor indicated on the public record of the debtor's jurisdiction of organization which shows the debtor to have been organized ...."38

Second, the revision narrowed error forgiveness under the "not seriously misleading" test to those errors that would be overcome by the search logic of the filing officer's computer program:

If a search of the records of the filing office under the debtor's correct name, using the filing office's standard search logic, if any, would disclose a financing statement that fails sufficiently to provide the name of the debtor in accordance with Section 9-503(a), the name provided does not make the financing statement seriously misleading. ${ }^{39}$

The "search logic" of a database program is the set of instructions that determine what strings of characters the program will treat as equivalent. The model regulations adopted in many states as a supplement to Revised Article $9,{ }^{40}$ for example, specify that punctuation, spaces, and capitalization are ignored in determining whether two strings of characters match. ${ }^{41}$ Under that rule, Ultra Magnetics Corporation is treated as the equivalent of

Data and Politics of Article 9 Filing, 79 MINN. L. REV. 663, 666 (1995) (referring to "[h]ow to minimize the aggregate costs of the filing system" as "an overriding issue in the [Article 9] revision process").

38 U.C.C. $\$ 9-503(a)(1)(2001)$.

39 U.C.C. $\$$ 9-506(c) (2001).

40 INTERNATIONAL ASSOCIATION OF CORPORATION ADMINISTRATORS, MODEL ADMINISTRATIVE RULES, UNIFORM COMMERCIAL CODE, REVISED ARTICLE 9, available at http://www.iaca.org/node/46 (last visited Jan. 27, 2007).

${ }^{41}$ E.g., IOWA ADMIN. CODE r. 721-30.5(4) (2001), available at http://www.legis.state.ia.us/Rules/2002/iac/721 iac/72130/72130.pdf (last visited Jan. 27, 2007) (stating that " $[\mathrm{h}]$ uman judgment does not play a role in determining the results of the search" and that punctuation, spacing, word abbreviations at the ends of names, the word "the" at beginning of search criteria, and case are ignored). 
UltraMagnetics Corporation, Ultra-Magnetics Corporation, and ultra magnetics corporation.

From the standpoint of the filer, the rule is a harsh one because virtually any spelling error other than (1) punctuation, spacing, and capitalization and (2) errors in "noise ending words" such as "Corp.," "Corporation," "Inc.," "Incorporated," "Company," "Co." and the like, renders the filing ineffective. Even those errors may not be forgiven by a particular local search logic. The errors that are fatal under this test include many spelling errors searchers had easily overcome prior to the revision. ${ }^{42}$ The benefit from adoption of this harsh rule was that in a system applying it, a searcher could conduct a single search in the exact, correct name of the debtor and be assured of finding every effective filing. ${ }^{43}$

Had the exact, correct name requirement been adopted in isolation, it might have invalidated thousands of filings each year. ${ }^{44}$ But the drafters also made a coordinated change intended to make exact, correct name filing and searching much easier.

\section{A Complete Solution to the Name-Error Problem}

Revised Article 9 changed the place for filing financing statements to the corporate debtor's state of incorporation. ${ }^{45}$ The effect was to put all Article 9 filings against a corporation into the state where the corporate records were kept. One purpose of that change was to make it feasible for the filing officers to fuse the two record systems. ${ }^{46}$ In effect, filers would file in the debtor's corporate record, and searchers would search that record. Fusion would make it possible for filers and searchers to select their corporate debtors from a list displayed on the computer screen, rather than typing those corporate debtors' names. Because filers and searchers would no longer have to type debtors'

42 The standard example of a minor error that would invalidate a filing in virtually every state is the misspelling of the debtor's correct name, "Tri State Moulded Plastics, Inc.," as "Tri State Molded Plastics, Inc." See In re Tyler, 23 B.R. 806 (Bankr. S.D. Fla. 1982) (invalidating the filing because of that error).

43 Pankratz Implement Co. v. Citizens Nat'l Bank, 102 P.3d 1165, 1168 (2006) ("This rule places the burden on the filing creditor to list the debtor correctly so searching creditors are under no obligation to conduct multiple searches using variations of the debtor's name.").

${ }^{44}$ E.g., Warner, supra note 1 , at 22 ("The new legal standard, coupled with strict search logic standards being adopted by filing offices, should make it much easier to challenge the perfection of a security interest on the basis of minor errors in the debtor's name.").

45 U.C.C. $\$ 9-307(e)$ (2001).

${ }^{46}$ Harris \& Mooney, supra note 37, at 669-70 (discussing benefits of that fusion). 
names, filers and searchers could no longer make errors in typing them.

A few states have already implemented such "point-and-click" systems. The Maine system, located at https://www.informe.org/ucc/filing/begin.shtml, is an example. In that system, one can elect to file a financing statement against a registered organization. The program then permits the user to enter a "full or partial debtor name." Entering "evergreen" produces a list of some two hundred Maine-registered corporations with the string "evergreen" in their names. The list shows the type of organization (for example, "ME CORP" "ME LLC" or "TX CORP"), the organization charter number, and the status of the organization (for example, "Good Standing" or "Suspended" or "Dissolved"). By clicking on the "select" button next to "TREFETHEN-EVERGREEN IMPROVEMENT ASSOCIATION" the user completes six fields ${ }^{47}$ of a financing statement which the user can file on-line. One of those fields is the debtor's name. Using this feature of the program, it is impossible for the user to make an error in entering the debtor's name, because the user does not enter the debtor's name.

Although it is not possible to misspell a debtor's name using this feature of the Maine system, it remains possible to file against the wrong debtor. An ideal implementation of this feature would display not just the type of organization, organization number, and status of the organization; it would display (or make readily available) all other information that is part of Maine's public record of this organization. In most states, that would include a corporate address and the names of officers or directors. Making this information readily available as part of the filing process would minimize the remaining possibility that the filer or searcher will misidentify the debtor.

Point-and-click on corporate names is an option in the Maine system. One can also type in the name of the corporation against which one wishes to file. Thus, name errors remain possible. But that need not be so. Filing officers could set up systems that permitted filing against registered organizations only by point-and-click. Had they done so prior to Spearing Tool, the IRS could not have made the error it did, and the Article 9 filing system would be completely free of corporate debtor name errors. Search logic would have been irrelevant to Article 9 filing and searching against corporations for the simple reason that every filer and searcher would have been filing and searching in precisely the correct debtor name. Reformers could then have moved on to the somewhat more difficult problem of individual names. ${ }^{48}$

47 The fields are: (1) Registered Organization Name, (2) State, (3) Country, (4) Organization ID, (5) Type of Organization, and (6) Jurisdiction of Organization.

48 Elsewhere, I have suggested an analogous system for filing against individuals: filing at the place of birth or at a place selected by the debtor at the time the debtor enters the system. To establish such a system, debtors would be required to file and update 


\section{THE SPEARING TOOL DECISION}

Crestmark Bank and Crestmark Financial Corp. (Crestmark), as creditors, entered into security agreements with Spearing Tool and Manufacturing Co. (Spearing Tool), as debtor, encumbering all of the debtor's assets. ${ }^{49}$ Crestmark perfected by filing financing statements with the Michigan Secretary of State in the exact, correct name of the debtor, both in April 1998 and in April $2001 .^{50} \mathrm{In}$ October 2001, the IRS filed two notices of federal tax liens against Spearing Tool with the Michigan Secretary of State. Both notices named the debtor as "SPEARING TOOL \& MFG COMPANY INC."'S1 On April 16, 2002, Spearing Tool filed under Chapter 11 of the Bankruptcy Code. ${ }^{52}$

The IRS claimed priority over Crestmark to the extent of the $\$ 153,058$ in advances made by Crestmark after the filing of the tax liens. ${ }^{53}$ The opinions do not state the basis for this claim, but it appears to be 26 U.S.C. $\S 6323(\mathrm{~d})$. That section gives a filed tax lien priority over disbursements made by even a prior secured lender if the disbursements are made more than forty-five days after the tax lien filing. ${ }^{54}$ In granting that priority, the section makes it necessary for secured lenders to conduct searches every forty-five days to avoid loss of priority to a tax lien. ${ }^{55}$ Searching every forty-five days is a heavy burden for a

records showing their identities and legal names. LoPucki, supra note 4, at 624-25. Kris Frederickson has proposed a system in which filers would submit the social security numbers of debtors and the filing offices would use them in matching searches to filings without disclosing the social security numbers to anyone. Kris Frederickson, A Solution to the UCC Article 9 Individual Name-Error Problem (undated manuscript, on file with the author).

49 United States v. Crestmark Bank (In re Spearing Tool and Mfg. Co., Inc.), (Spearing Tool III), 412 F.3d 653, 654 (6th Cir. 2005).

50 Id.

51 Id.

52 Id. at 655.

53 In re Spearing Tool and Mfg. Co., Inc. (Spearing Tool II), 302 B.R. 351, 353 (Bankr. E.D. Mich. 2003).

5426 U.S.C. $\S 6323$ (d) (2000) provides: "Even though notice of a lien imposed by section 6321 has been filed, such lien shall not be valid with respect to a security interest which came into existence after tax lien filing by reason of disbursements made before the 46th day after the date of tax lien filing ...."

55 See, e.g., Tex. Oil \& Gas Corp. v. United States, 466 F.2d 1040, 1053 (5th Cir. 1972) ("As the law appears to stand, the commercial lender must check the applicable records every forty-five days or else seriously jeopardize his security under the varying degrees of rigor promulgated by the choateness doctrine."). This search burden is itself unreasonable because secured lenders have already identified themselves to competing lienholders by filing financing statements. A reasonable system would require the IRS to conduct a search at the time it filed the tax lien and notify each secured lender of record of the filing. That 
secured creditor, but Crestmark apparently met it. The Sixth Circuit's opinion states that Crestmark searched "periodically" in the exact, correct name of Spearing Tool. ${ }^{56}$ Those searches did not discover the IRS's liens, because the IRS's notices were not filed in the exact, correct name of Spearing Tool, and the Michigan Secretary of State's search logic was inadequate to overcome the IRS's error.

Crestmark filed a complaint with the bankruptcy court to determine lien priority. ${ }^{57}$ The bankruptcy court granted summary judgment against Crestmark, reasoning that (1) federal law governed the form of a tax lien notice ${ }^{58}(2)$ federal law required only that the notice "identify the taxpayer," 59 and (3) the IRS had identified the taxpayer. The court held the reasonably diligent search test inapplicable because the court thought the IRS had made no error in Spearing Tool's name. The IRS had "used the accepted abbreviation for the word 'Manufacturing." 60 For this proposition, the court cited Webster's New Collegiate Dictionary and The Bluebook. ${ }^{61}$

District Judge Nancy G. Edmunds, the lone hero in this judicial saga, reversed. She agreed with the bankruptcy court that federal law governed. ${ }^{62}$ She correctly reasoned that federal law made the reasonably diligent search test applicable. ${ }^{63}$ But she held that the abbreviated name was not sufficient to identify the taxpayer under that test because it was not reasonable for searchers to have "to conduct separate, multiple searches under the debtor's multiple

single search and notice would obviate the necessity for multiple searches at forty-five-day intervals by the secured lenders. An analogous problem arises with respect to purchase money secured lending against inventory under Article 9 . That problem has been dealt with by requiring the purchase money lenders in the position analogous to the IRS to conduct searches and give notice. U.C.C. § 9-324(b) (2001).

56 "Crestmark periodically submitted lien search requests to the Michigan Secretary of State, using Spearing's exact registered name." United States v. Crestmark Bank (In re Spearing Tool and Mfg. Co., Inc.) (Spearing Tool III), 412 F.3d 653, 655 (6th Cir. 2005).

57 Id. at 655.

58 In re Spearing Tool \& Mfg. Co. (Spearing Tool I) 292 B.R. 582, 582 (E.D. Mich. 2003).

59 Id.

$60 \mathrm{Id}$. at 583.

$61 \mathrm{Id}$.

62 In re Spearing Tool and Mfg. Co., Inc. (Spearing Tool II), 302 B.R. 351, 355 (E.D. Mich. 2003) ("The issue thus becomes whether the lien in this case complied with federal law.").

${ }^{63}$ Id. ("In cases where the government has made errors in the debtor's name on the lien, courts inquire whether a reasonable search of the index would have disclosed the error-laden federal tax lien."). 
possible names for a possible federal tax lien."64 Judge Edmunds reversed the government's grant of summary judgment and remanded the case to the bankruptcy court.

The court of appeals agreed with the district court that the reasonably diligent search test of federal law applied, but concluded that conducting a single search in the exact, correct name of the debtor was not reasonable and diligent. ${ }^{65}$ The court opined that:

Crestmark should have searched here for "Spearing Tool \& Mfg." as well as "Spearing Tool and Manufacturing." "Mfg." and the ampersand are, of course, most common abbreviations-so common that, for example, we use them as a rule in our case citations. Crestmark had notice that Spearing sometimes used these abbreviations, and the Michigan Secretary of State's office recommended a search using the abbreviations. Combined, these factors indicate that a reasonable, diligent search by Crestmark of the Michigan lien filings for this business would have disclosed Spearing's IRS tax liens.

... Here ... only two relevant words could be, and commonly are, abbreviated: "Manufacturing" and "and"-and the Secretary of State specifically recommended searching for those abbreviations.... Our holding is limited to these facts. ${ }^{66}$

Had the court stopped there, the opinion could fairly be read to require only that searchers search in names suggested to them by the filing office. ${ }^{67}$ But the court continued:

Finally, we note that policy considerations also support the IRS's position. A requirement that tax liens identify a taxpayer with absolute precision would be unduly burdensome to the government's tax-collection efforts. Indeed, such a requirement might burden the government at least as much as Crestmark claims it would be burdened by having to perform multiple lien searches.... Further, to subject the federal government to different identification requirements-varying with each state's electronic-search technology-would run counter to the principle of

64 In re Spearing Tool and Mfg. Co., Inc. (Spearing Tool II), 302 B.R. at 357.

65 "So the question for this case becomes whether Crestmark conducted a reasonable and diligent electronic search. It did not." United States v. Crestmark Bank (In re Spearing Tool and Mfg. Co., Inc.) (Spearing Tool III), 412 F.3d 653, 656 (6th Cir. 2005).

66 Id. (emphasis in original).

${ }^{67} \mathrm{Had}$ the court stopped there, the results might still have been disastrous. Any time a filing office made a suggestion for additional searches, the secured creditor would have had to conduct those searches or risk subordination to a filing that might have been found. It would be the responsibility of every searcher to be aware of this obligation. 
uniformity which has long been the accepted practice in the field of federal taxation.

Crestmark urges us to require IRS liens to meet the same precise-identification requirement other lien notices now must meet under Uniform Commercial Code Article 9. ... We decline to do so. ...

More importantly, the Supreme Court has noted that the United States, as an involuntary creditor of delinquent taxpayers, is entitled to special priority over voluntary creditors. Thus, while we understand that a requirement that the IRS comply with UCC Article 9 would spare banks considerable inconvenience, we conclude from Supreme-Court precedent that the federal government's interest in prompt, effective tax collection trumps the banks' convenience in loan collection. ${ }^{68}$

While the opinion is unclear as to precisely what searchers must do, it is clear that their obligation is not limited to a single search in the exact, correct name of the debtor. In at least some circumstances, they must do something more.

\section{A SySTEMS/STRATEGIC ANALYSIS OF THE SPEARING TOOL DECISION}

Spearing Tool will have both immediate and long-term effects on the filing system. The immediate effects will be to increase the costs and reduce the effectiveness of searching. The longer-term effects will be to block debtor name reform and generate pressure to relax the debtor name requirement for Article 9 filers.

\section{A. Immediate Systems Effects}

The systems/strategic approach I have elaborated elsewhere ${ }^{69}$ provides a method for determining the likely effects of Spearing Tool on the functioning of the filing system. As applied here, that method is to specify the system with and without the feature under consideration, conduct strategic analyses of each of the two specified systems, and then compare the results. ${ }^{70}$ Strategic analysis

68 Spearing Tool III, 412 F.3d at 656-57 (internal quotations and citations omitted).

69 See generally Lynn M. LoPucki, The Systems Approach to Law, 82 CoRNELL L. REV. 479 (1997) [hereinafter LoPucki, Systems Approach]; Lynn M. LoPucki, Twerski and Cohen's Second Revolution: A Systems/Strategic Perspective, 94 Nw. U. L. REV. 55 (1999) [hereinafter LoPucki, Systems/Strategic Perspective].

70 LoPucki, Systems/Strategic Perspective, supra note 69, at 70-75 (comparing the CABG surgery delivery subsystem with the system that would result from Twerski and Cohen's proposal). 
is accomplished by hypothetically placing one's self in the positions of the various system participants, and asking what strategies each would be likely to pursue in response to each of the rules under consideration. ${ }^{71}$ If those strategies interact, the analyst projects the likely resolution and ultimately arrives at an informed guess at how the resulting system would function under each rule.

The systems to be compared are the Article 9 filing systems, including the subsystems by which the Internal Revenue Service and other secured creditors prepare their filings and conduct searches, under two alternative rules regarding debtor-name-errors. The rules are those adopted by the District Court in Spearing Tool (federal tax lien filings must comply with the Article 9 rule) and by the Court of Appeals in Spearing Tool (federal tax lien filings need not comply with the Article 9 rule).

\section{Strategy Under the Article 9 Rule}

The Article 9 filing system is the proper place for filing Article 9 financing statements in all states, for filing tax lien notices in most states, ${ }^{72}$ for filing judgment liens against personal property in a few states, ${ }^{73}$ and for filing a few other kinds of liens in still other states. ${ }^{74} \mathrm{I}$ am aware of no statutes requiring filing in the Article 9 filing system and imposing a test for name validity different from the Article 9 rule. ${ }^{75}$ If the Spearing Tool court had held the

${ }^{71}$ LoPucki, Systems Approach, supra note 69, at 507.

72 UNIFORM COMMERCLAL CODE REVISEd ARTICle 9 Alert: A STATE-BY-STATE GUIDE TO SEARCHING AND FILING UNDER THE NEW REVISION § 8-1-6 (Carl R. Ernst ed., 2000-2005) [hereinafter ARTICLE 9 ALERT] (table showing twenty-seven states, including New York, California, Texas, Florida, and Illinois, with laws directing that the IRS file tax liens in the office of the Secretary of State).

73 See, e.g., CAL. CIV. Proc. CODE $\S 697.510$ (a) (West 2002) (providing that "A judgment lien on personal property ... is created by filing a notice of judgment lien in the office of the Secretary of State pursuant to this article.").

74 For example, in Hawaii, Article 9 filings are made in the "bureau of conveyances." Haw. ReV. STAT. ANN. § 490:9-501(a)(2)(LexisNexis 2002). That office combines them with federal tax liens, judgment liens, real property conveyances and other kinds of documents in an "official records" system. HAw. CODE R. § 13-16-31 (1997), available at http://www.hawaii.gov/dlnr/bc/AR4599.pdf (last visited Feb. 3, 2007) (providing for the recording of UCC financing statements and a variety of other documents in an official-book-and-page recording system in the bureau of conveyances); see also International Association of Commercial Administrators, Non-UCC Lien Search Request Survey Results from State Level Filing Offices as of 5/1/2006, available at http://www.iaca.org/downloads/2006Conference/STS/Non-UCC_Lien_Search_Request_ Survey_Results 512006.pdf (last visited Feb. 3, 2007).

75 See, e.g., CAL. CIV. ProC. CODE $§ 697.550($ b) (West 2002) (specifying that in 
federal test for name validity on tax liens to be the same as the Article 9 rule, a searcher's best strategy would have been to search only in the exact, correct name of the debtor. Such searches would quickly have become customary and no other court would likely have held them unreasonable. ${ }^{76}$ Persons searching only in the exact, correct name of the debtor would have been assured of finding all effective filings against their debtors.

Searching and filing in the exact, correct name would not have been difficult because the searcher could have determined the exact, correct name by visiting the website of the Corporations Division of the Secretary of State in the state of their debtor's incorporation. The IRS has the information necessary to do that. The IRS knows the state in which to seek the debtor's name because every taxpayer must have a taxpayer identification number, and the IRS collects the state of organization as part of the number-issuance procedure. ${ }^{77}$ The IRS might also find it helpful to know the state-issued corporate organizational number, because it would give the IRS a double check on identity. If so, the IRS could easily obtain the number by amending its SS-4 form. ${ }^{78}$

If the IRS nevertheless filed in a seriously misleading name, the IRS would lose its priority. However, as will be explained below, such losses could have been entirely eliminated for the IRS and other filers by filing office implementation of point-and-click filing systems.

California a notice of judgment lien "shall contain ... the name... of the judgment debtor" but not further addressing the issue of search validity); $\S 697.670(\mathrm{~b})$ (authorizing the Califomia Secretary of State to prescribe the form for notice of a judgment lien and deeming such form to "supersede[] any requirements specified [in the statute]"). No reason exists for legislatures or courts to establish separate name-error standards. Such establishment would have been particularly unlikely if the Sixth Circuit in Spearing Tool had held the IRS bound to the Article 9 name-error validity standard. Absent such a construction, I contend that lenders conducting Article 9 searches would have relied on single searches in the exact, correct names of their debtors even with respect to the largest loans.

${ }^{76}$ Presumably, the court would have opined that filing in a version of the debtor's name would have made the filing invisible to the statutorily-authorized search method because the system did not "identify" the debtor. At that point, the system would have been functioning efficiently and the disruptive effects of a contrary ruling would have been apparent. This reasoning applies both to rulings regarding tax liens and other types of non-Article 9 filings required to be made in the Article 9 system.

77 See IRS Form SS-4, Application for Employer Identification Number (OMB No. 1545-0003) (Rev. Feb. 2006) § 1 ("Legal name of entity"); $\S 8$ b ("If a corporation, name the state or foreign country ... where incorporated"), available at http://www.irs.gov/app/scripts/retriever.jsp (click on 0206 Form SS-4(PDF) Application for Employer Identification Number).

78 See generally id. 
The cost to the IRS of learning corporate taxpayers' exact, correct names might have been entirely offset by added benefits. Knowing taxpayers' exact, correct names would have given the IRS the ability to match documents that lacked tax identification numbers or contained erroneous tax identification numbers to taxpayers. When the IRS found itself in the position of searcher, it would have benefited, like any other searcher, from a system in which a single search in the exact, correct name found all effective filings. If these benefits were large enough to offset the costs, the net cost of adopting the Article 9 rule would have been zero.

Carl R. Ernst, a leading expert on public records searching, argues that filers and searchers cannot be safe in relying on the name of a corporation as it appears on the website of the Secretary of State of the debtor's state of incorporation, because the name on the website might be wrong. He cites the example of New Hampshire, where the practice appears to be to invert individual names within corporate names on the Corporations Division website. ${ }^{79}$ To illustrate, Shane Smith Industries, LLC is displayed as Smith, Shane, Industries, LLC. To make matters worse, a search for "Shane Smith Industries, LLC"-apparently the exact, correct name of this entity-reports no record found. One must search in the inversion to find the record and, even then, one cannot be sure it is an inversion. Ernst would accommodate such sloppy practices by interpreting the U.C.C. section 9-503(a)(1) reference to "the name of the debtor indicated on the public record of the debtor's jurisdiction of organization" as being to "the actual filed organization document."80

The problem Ernst raises is real, and the practice of the New Hampshire Secretary of State is unfortunate. The solution, however, is not to plunge the filing system back into the twentieth century by requiring filers and searchers to order hard copies of corporate documents or to search in name variations. The solution is to change the New Hampshire Secretary of State's practice.

In the meantime, the courts should interpret the U.C.C. section 9-503(a)(1) requirement and the New Hampshire listings as they were intended. The reference to "the name of the debtor indicated on the public record" is best read as a reference to the name as it is displayed on the Secretary of State's website. ${ }^{81}$ Documents not available on-line without the payment of a fee

${ }^{79} \mathrm{New}$

Hampshire

Corporate

Division, https://www.sos.nh.gov/corporate/soskb/csearch.asp (last visited Jan. 27, 2007).

${ }^{80}$ Email from Carl R. Ernst, President of Ernst Publishing Co., LLC, to Lynn M. LoPucki, Security Pacific Bank Professor of Law, UCLA Law School (Aug. 21, 2005, 02:56 PST) ("A call or look at the corporate index will not ... obtain the correct debtor name for a registered organization. The only acceptable source of the name is the actual filed organization document.").

81 See, e.g., William D. WarRen \& Steven D. Walt, SeCuREd Transactions IN 
should not be considered "public" for this purpose, because the public has no reasonable means of access to them. Nor should the debtor's name in documents that are available on-line be considered authoritative. A rule that required the searcher to inquire beyond the name listed on the Secretary of State's website would be incompatible with point-and-click ${ }^{82}$ and would require extra steps without adding significantly to system function. ${ }^{83}$ The New Hampshire internet display is best understood not as a second name for the same corporation, but as a different display of the same name. Until New Hampshire ends its confusing practice, the courts - and the IRS - should read "Smith, Shane, Industries, LLC" as "Shane Smith Industries, LLC." That is what the New Hampshire Secretary of State obviously intends.

\section{Strategy Under the Sixth Circuit's Rule}

The first step in determining the strategic response to the Sixth Circuit's rule is to operationalize the rule-that is, to state concretely what courts that follow it will do. As is common in court opinions, the Sixth Circuit makes contradictory statements in that regard. For example, the court states that: "[w]e express no opinion about whether creditors have a general obligation to search name variations. Our holding is limited to these facts." 84 But elsewhere, the court makes statements supporting three broader interpretations:

(1) The court says that: "Crestmark had notice that Spearing sometimes used these abbreviations, and the Michigan Secretary of State's office recommended a search using the abbreviations." 85 This language suggests that searchers who have actual knowledge of a name variation should search in that name variation and that future courts should so hold.

PERSONAL PROPERTY 67 (6th ed. 2004) (stating that the "correct name" of a corporate debtor "is available by computer search").

82 For example, if the version of the debtor's name that appeared on the articles of incorporation and amendments thereto were considered the exact, correct name, the effect would be to invalidate all filings made by point-and-click against an improperly-indexed debtor. Article 9 generally takes the opposite position. Filing office errors in indexing records do not render the incorrectly indexed records ineffective. U.C.C. $\$ 9-517$ (2001) ("The failure of the filing office to index a record correctly does not affect the effectiveness of the filed record.").

83 If the documents filed with the Secretary of State were authoritative, each filer and searcher would be required to examine the articles of incorporation and all amendments that might contain name changes. Few filers and searchers would have any way to find those documents except by first finding the debtor's name in the index. Thus, examination of the articles and amendments would be extra work, not substitute work.

84 United States v. Crestmark Bank (In re Spearing Tool and Mfg. Co., Inc.) (Spearing Tool III), 412 F.3d 653, 656 (6th Cir. 2005).

85 Id. (emphasis in original). 
(2) The court notes that: "'Mfg.' and the ampersand are ...common abbreviations-so common that, for example, we use them as a rule in our case citations." 86 While this statement in itself suggests a duty to search under common abbreviations of names, the court brushes aside Crestmark's example of a name that could be abbreviated 288 different ways by saying: "[h]ere, however, only two relevant words could be, and commonly are, abbreviated." 87 Together, these statements suggest that searchers have an obligation to search small numbers of common abbreviations but not large ones, and that future courts should so hold.

(3) The court states that: " $[t]$ he critical issue in determining whether an abbreviated or erroneous name sufficiently identifies a taxpayer is whether a 'reasonable and diligent search would have revealed the existence of the notices of the federal tax liens under these names." 88 The court then identifies as "the question for this case ... whether Crestmark conducted a reasonable [sic] diligent electronic search." 89 This language suggests that future courts should pose the same open-ended question-in other words, apply the reasonably diligent search rule.

Thus, the opinion deliberately suggests at least four variants of its rule, and declines to say which variant courts should adopt. Courts that "follow" the Sixth Circuit could adopt any of the four positions. The effect is to render future decisions generally uncertain, but one aspect of them certain. Courts following the Sixth Circuit will not rule that a notice of tax lien is invalid solely because a search of the filing office in the exact, correct name of the debtor will not discover the tax lien.

\section{a. Searcher Strategy}

Searchers have at least four techniques for dealing with the uncertainty created by the Sixth Circuit rule. First, they can expand their searches to include some name variations. ${ }^{90}$ At a minimum, searchers would include variations of which they have been given actual notice and might also include

${ }^{86} \mathrm{Id}$.
${ }^{87} \mathrm{Id}$.
${ }^{88} \mathrm{Id}$.
${ }^{89} \mathrm{Id}$.

90 Margit Livingston, Survey of Cases Decided Under Revised Article 9: There's Not Much New Under the Sun, 2 DEPAul Bus. \& COM. L.J. 47, 53 (2003) ("Anticipating common variant spellings (e.g., 'MFG' for 'Manufacturing') and using truncated portions of the debtor's name (e.g., 'Spearing Tool') will continue to be useful searching techniques."); Long, supra note 23, at 64 (stating in the wake of the bankruptcy court's decision in Spearing Tool that "[p]rudence would dictate a more extensive search using variations of the correct name"). 
common abbreviations. Carl R. Ernst suggests that searchers obtain a copy of the debtor's tax returns-from multiple years in order to assure that the debtor has not changed its name-and search in the name variations on those returns. ${ }^{91}$ Even so extensive an effort would not yield certainty, however, because the Sixth Circuit did not hold the IRS bound to correctly transcribe the taxpayer's name from the return to the notice. Regardless of the degree of one's diligence, one could never be certain that the reasonably diligent searcher would not have done something different. ${ }^{92}$

A second technique for searchers to respond to Spearing Tool would be development of systems for retaining and acting on notices of possible name variations. For example, a searcher may want to keep a "name variation file" for each of its debtors and conduct its periodic searches in those variations. Third, searchers can purchase insurance against the risk of undiscovered tax liens. Fourth, they can assume the risk of undiscovered tax liens. With respect to a particular loan, a lender can employ some combination of these techniques, perhaps conducting an expanded, but not exhaustive search.

Assuming the risk of undiscovered tax liens may provide a complete solution for many searchers. But those contemplating large advances will need to search for tax liens. The IRS files more than half a million tax liens annually ${ }^{93}$ and the large majority of those filings are in the Article 9 filing systems. ${ }^{94}$ By comparison, secured creditors file about three million initial financing statements each year. Tax liens can be for millions of dollars. Thus it may be cost effective for some searchers to spend thousands of dollars searching for tax liens that are not revealed on a search in the exact, correct name of the debtor.

Professors Steven L. Harris and Charles W. Mooney, Jr. suggest three additional strategies for discovering tax liens:

One possibility is to utilize the services of private firms that maintain "shadow" records of tax-lien filings. These records often can be searched with a broader search logic than the filing office's standard search logic....

91 ARTICLE 9 ALERT, supra note 72, at $§ 4-4-5$ ("Therefore, you may need to obtain tax returns from multiple years in order to assure yourself that the debtor has not changed its name on any tax returns anytime during the past few (up to 10) years.").

92 E.g., Financing Statements, supra note 23 (quoting Crestmark's attomey, Steven Ross, that "no search for federal tax liens will ever assure complete protection [after Spearing Tool]").

93 See I.R.S., SOI Tax Stats-Enforcing Laws, at Table 16, available at http://www.irs.gov/pub/irs-soi/04dbl6co.xls (last visited Jan. 27, 2007) (indicating that 534,392 tax liens were filed in 2004).

${ }^{94}$ See supra note 72 (states require most tax lien filings to be made with Secretaries of State). 
Depending on the size of the transaction, before extending credit a secured party may wish to conduct an audit of the debtor's finances to determine whether the debtor has outstanding tax liability. A less costly approach is to file IRS Form 8821, in which the debtor (taxpayer) may authorize the secured party to inspect and receive both present and future confidential tax information. ${ }^{95}$

While these methods might be useful supplements to an official Article 9 search for tax liens, none is a likely substitute. Privately maintained databases of tax liens are compiled from the public records, so that a tax lien may show up only days or weeks after it takes effect. The searcher would still need to search the Article 9 filing system for more recently filed liens. The audit is not only expensive, but would miss tax liens filed against debtors who maintain-and show on their books-that they don't owe the taxes. Form 8821 merely notifies the IRS that the appointee is authorized "to inspect and/or receive [the taxpayer's] confidential information in any office of the IRS." "96 The secured party would still have to make arrangements with the IRS for those inspections. If the searcher requests copies, the searcher is at the mercy of the IRS as to when the copies are sent. Even creditors who adopt one of these methods would likely continue to conduct official searches designed to find not only Article 9 filings, but also federal tax liens.

\section{b. IRS Strategy}

The IRS "won" Spearing Tool. But the opinion creates as much uncertainty for the IRS as a filer as it does for searchers. The IRS has no way of knowing whether its next abbreviated filing will be effective. Hence, it might seem to be a good idea for the IRS to begin discovering the exact, correct names of corporate taxpayers and filing under them. I doubt, however, that the IRS will do that. As victors in the case, it seems more likely that it will consider its methods vindicated and continue to use them, even if filing in exact, correct names would be more cost-effective.

\section{Cost Comparisons}

The next step is to compare the costs of the entire system under the two alternative rules. In making this comparison, I consider only costs that a party would incur under one of the rules that the party would not incur under the

95 STEVEn L. Harris \& Charles W. MOONEy, JR., Security INTEREsts in PERSONAL Property, CASES, Problems AND MATERIALS 541 (4th ed. 2006).

96 I.R.S. Form 8821 (2004), available at http://www.irs.gov/pub/irs-pdf/f8821.pdf (last visited Jan. 27, 2007). 
other. The results of this comparison are shown in the following Table.

The Table shows that the Sixth Circuit rule will impose six kinds of costs on searchers that the Article 9 rule would not. Searchers will incur costs to search in name variations, to insure that notices of name variations are acted on, to purchase insurance against name errors, to pay for loss of priority disputes, to litigate over the ambiguities in the Sixth Circuit's rule when their security interests are subordinated to tax liens, and to decide what strategies to pursue in particular cases to minimize their costs. The cost of deciding among strategies may well be the largest cost because the decision will require the exercise of judgment by sophisticated professionals. ${ }^{97} \mathrm{~A}$ mechanical decision algorithm is inadequate because data do not yet exist to quantify the risks of undiscovered tax liens. In addition, the Sixth Circuit rule will remain in flux until at least some of its ambiguities are resolved.

\begin{tabular}{|c|c|c|}
\hline \multicolumn{3}{|c|}{ Table: Costs of Parties Under the Alternative Rules ${ }^{a}$} \\
\hline & Article 9 Rule & Sixth Circuit Rule \\
\hline Lenders & & $\begin{array}{l}\text { 1. Name-variation search costs } \\
\text { 2. Notice-reception costs } \\
\text { 3. Insurance costs } \\
\text { 4. Priority losses (substantial) } \\
\text { 5. Judgment-exercise costs } \\
\text { 6. Litigation costs (substantial) }\end{array}$ \\
\hline IRS & $\begin{array}{l}\text { 1. Cost of discovering } \\
\text { exact names (minimal) } \\
\text { 2. Priority losses } \\
\text { (minimal) }\end{array}$ & Litigation costs (substantial) \\
\hline Courts & & Litigation costs (substantial) \\
\hline
\end{tabular}

Those ambiguities will be resolved through litigation that will impose costs on the IRS, lenders, and the court system. The costs will be substantial because the courts will have to rule on a large number of cases in order to flesh out the meaning of the "reasonably diligent search" test under federal law.

Had the Sixth Circuit adopted the Article 9 standard instead, future litigation would have been minimal. The only real issue at that point would

${ }^{97}$ On the largest loans, those professionals theoretically might decide that if tax liens were filed against the debtor-for example, General Motors - those liens would be reported by the media. But that essentially delegates the search function to journalists, something few lawyers would choose to do. 
have been whether other courts would follow the Sixth Circuit. Unless the IRS could have raised the issue quickly at the circuit level in another case, the IRS probably would not have raised it at all. ${ }^{98}$ Establishing procedures for discovering the exact, correct names of corporate taxpayers would have been cheaper. Once the IRS did that, its losses of priority would have been minimal, leaving it with inadequate incentives to litigate further.

The IRS will receive a benefit from the Sixth Circuit rule that is not shown on the table. Under the Sixth Circuit rule, some lenders will not discover effective tax liens and will make advances that are subordinate to the liens. Some of the value those lenders advance may still be in the hands of their debtors when the IRS finally takes collection action. The IRS may capture some of that value. From a systems viewpoint, however, the existence of those advances provides no support for the rule. When such advances were made, lenders would lose much more than the IRS would gain. ${ }^{99}$ The system as a whole would be operating inefficiently.

The IRS is the only party that may gain from the Sixth Circuit rule. If there are gains, however, they will be limited to (1) the costs the IRS would have incurred for checking corporate names under the Article 9 rule and (2) the value of the IRS liens that would have been avoided for name error under the Article 9 rule. Savings from the first are minimal because records of incorporation are now available on-line and the IRS already knows the state of incorporation for every corporate taxpayer. Savings from the second would cease to exist as soon as point-and-click systems were in place.

The Sixth Circuit claims in its opinion that "[a] requirement that tax liens identify a taxpayer with absolute precision would be unduly burdensome to the government's tax-collection efforts. Indeed, such a requirement might burden the government at least as much as Crestmark claims it would be burdened by having to perform multiple lien searches." 100 The court offers no support for this proposition and the analysis presented here demonstrates its falsity.

The court further claims that "to subject the federal government to different identification requirements-varying with each state's electronic-search technology-'would run counter to the principle of uniformity which has long been the accepted practice in the field of federal

98 The IRS is one of many repeat litigators who gain advantage by manipulating the courts in which issues of general interest to the IRS arise. See Lynn M. LoPucki \& Walter O. Weyrauch, $A$ Theory of Legal Strategy, 49 DUKE L.J. 1405, 1450-52 (2000) (describing the "case selection strategy" generally); id. at $1451 \mathrm{n} .219$ (reporting its use by the IRS).

99 Debtors will spend some portion of the funds advanced, so neither the lender nor the IRS will have the advantage of them.

100 United States v. Crestmark Bank (In re Spearing Tool and Mfg. Co., Inc.) (Spearing Tool III), 412 F.3d 653, 656 (6th Cir. 2005). 
taxation." "101 In fact, the Article 9 rule would not subject the government to different identification requirements. From the IRS's viewpoint as a filer, the Article 9 requirement would have been functionally identical in every one of the fifty states: file in the exact, correct name of the debtor. ${ }^{102}$ An erroneous filing that rendered the filing ineffective in one state might be saved by the search logic of another, with the result that the IRS might suffer slightly greater losses in one state than another. No strategy would exist, however, by which the IRS could reasonably hope to reduce its costs or losses by adopting different filing strategies in different states. ${ }^{103}$ Under the Article 9 rule, the IRS's best strategy would have been to ignore the search logic of the state, and concentrate on getting the name exactly correct. Thus, the Sixth Circuit's rule imposes substantial costs on lenders, while providing little or no benefit to the IRS.

\section{B. Effects on Future System Development}

The drafters intended revised Article 9 to confer on lenders the ability to search in the exact, correct name of the debtor and be assured that they had found all effective filings against the debtor. ${ }^{104}$ Ultimately, the hope was to achieve name-error-free filing and searching by point-and-click and perhaps even filing-office notification to filers of corporate status changes that affected the validity of filings. ${ }^{105}$

At the time the Sixth Circuit decided Spearing Tool the legal basis for an exclusively point-and-click system was not yet entirely in place. For one thing, the Internal Revenue Code still mandates notice of tax lien filing in the jurisdiction in which the debtor's principal executive office is located. ${ }^{106}$ If Spearing Tool had subjected the IRS to the Article 9 name rule, the IRS would have been able to obtain exact, correct names from the websites of corporate taxpayers' states of incorporation. But the IRS would not always have been able to use a point-and-click system for filing and searching. In perhaps ten

101 Id. at 657 (citation omitted).

102 U.C.C. $\$ 9-503(a)$ (2001).

103 For example, if one state's search logic validated abbreviation of "manufacturing" as "mfg," there is no policy the IRS could adopt as a filer to gain advantage from that fact.

104 See infra note 119 and accompanying text.

105 Harris \& Mooney, supra note 37, at 669 ("An incorporation-based choice-of-law rule might facilitate the transmission of relevant information to secured parties and thereby obviate the need for periodic searches ....").

10626 U.S.C. $\$ 6323(\mathrm{f})(1)-(2)(2000)$ (requiring that the notice be filed in the state in which the property subject to the lien is situated, deeming the property to be situated at the residence of the taxpayer, and deeming the residence of a corporate taxpayer to be at its principal executive office). 
percent of IRS filings, ${ }^{107}$ the principal executive office would be in a state other than the taxpayer's state of incorporation.

The IRS's disadvantage in that regard probably would not have lasted long. The IRS would have prevailed upon Congress to change the place for tax lien filing to the state of incorporation - a rule already demonstrated to be more favorable to filers. ${ }^{108}$ The IRS might also have sought a rule requiring that all federal tax lien filings be in the Article 9 filing systems. ${ }^{109}$ Consolidating the IRS's filings in the Article 9 system of the debtor's state of incorporation would in turn have created pressures to consolidate other kinds of lien filings there. ${ }^{110}$ For example, a California bankruptcy court has already construed a California statute requiring the filing of a notice of judgment lien "in the office of the Secretary of State" to refer to the Secretary of State of the debtor's state of incorporation. ${ }^{11}$ The remaining barriers to an Article 9 filing system that revealed every public lien filing in response to a single search would have fallen like dominoes.

Spearing Tool now stands in the way of that development. Some effective filings in the Article 9 system cannot be found on a single search in the exact, correct name. No state can adopt an exclusively point-and-click system for filing in the Article 9 records because the IRS may need to file in the state against a corporation incorporated in another state. As long as one must search for IRS liens in states other than the state of incorporation, little is to be gained by moving other kinds of liens to the state of incorporation. As the "winner" in Spearing Tool, the IRS has only modest incentives to fix these problems.

Now that Spearing Tool prevents debtor-name-error elimination, the

107 To my knowledge, no published data on this point exist. The $10 \%$ figure I use is an estimate based on these assumptions. First, less than $5.3 \%$ of all U.C.C. filings are made against Delaware corporations that are located outside Delaware. This assumption is based on my finding that 245,736 of the $4,607,113$ U.C.C. filings made in $1993(5.3 \%)$ were made against Delaware corporations outside Delaware. LoPucki, supra note 4 , at 644 . The current percentage is probably lower than the historical one because former Article 9 required multiple filings against companies with collateral in multiple states. Second, filings against registered entities are about half of all U.C.C. filings. Third, tax lien filings against these corporations will be in roughly the same proportions as U.C.C. filings.

108 The principal advantage to the filer is that the debtor's place of incorporation is easier to determine than is the location of the debtor's chief executive office, because the former is a matter of public record while the latter is often a matter of opinion. LoPucki, supra note 4 , at 593-602.

109 Some are currently held in local offices. See ARTICLE 9 ALERT, supra note 72, at § 8-1-6 (indicating that local filing is required in about eighteen states).

110 Agricultural liens, for example, are still filed in the jurisdiction where the collateral is located, even if the debtor is incorporated elsewhere. U.C.C. § 9-302 (2001).

${ }^{111}$ Aura Systems, Inc. v. Barovich (In re Aura Systems, Inc.), 347 B.R. 720, 724-25 (Bankr. C.D. Cal. 2006). 
dominos may well fall the other way. Reformers will argue that revised Article 9 failed to deliver on its promise that a single search could discover all effective filings. Searchers must be sufficiently diligent to overcome the various kinds of errors the IRS makes and the abbreviations it uses on tax liens. That same diligence will overcome the same kinds of errors made and abbreviations used on Article 9 financing statements. Given that the searchers must search for the errors and abbreviations anyway, it makes little sense to invalidate Article 9 filings for making those errors or using those abbreviations. Elimination of the exact, correct name requirement for Article 9 filers can benefit those filers without imposing additional costs on searchers. Thus filing system reform may march back down the hill it spent the past fifteen years marching up.

This retreat could occur even without legislative action. In discussing the long term effects of Spearing Tool, one commentator pointed out that:

Those of us who are going to be extra cautious will actually search more broadly, even though the statute only requires a search of the exact registered name. Sooner or later, more judges are going to ask what people really do and we are going to have to say we search broadly. The judges will eventually say if that is what a reasonable person does, then that is how we will interpret [U.C.C. section 9-506(c)]. ${ }^{112}$

Professors William Warren and Steven Walt have already proposed an interpretation of U.C.C. section 9-506(c) that would support such a result. ${ }^{113}$

\section{Did the Law Make Them Do It?}

Judges who make a mess of social systems are usually quick to claim that the law left them no alternative. Weyrauch and I have argued elsewhere that this claim is never true. ${ }^{114}$ It is certainly not true here.

The Sixth Circuit reasoned that: (1) federal law governed the form of a tax lien; (2) federal law required only that the notice "identify the taxpayer"; and (3) the reasonably diligent search test determined whether the name given identified the taxpayer. The court cited three cases applying the reasonable searcher test. ${ }^{115}$ Two of the three, however, made clear that while the

112 Ingrid Michelson Hillinger et al., The Latest Developments in Article 9, 2 DEPAUL BUS. \& COM. L.J. 675, 683 (2004) (transcript report of the comment of an unidentified audience member).

113 WARREN \& WALT, supra note 2, at 70-71 (arguing that U.C.C. $\S 9-506$ (c) by its terms validates filings, but does not invalidate filings).

114 LoPucki \& Weyrauch, supra note 98, at 1471-82.

115 United States v. Crestmark Bank (In re Spearing Tool and Mfg. Co., Inc.) 
reasonably diligent search test is a federal test, that federal test looks to how the state keeps the records and permits their search to determine what is reasonable. ${ }^{116}$ What constitutes a "reasonably diligent search" under federal law is different from state to state, depending on characteristics of the state's record system and the methods of search permitted. ${ }^{117}$

The states' systems for searching changed abruptly with the enactment of Revised Article 9. Although private database searches remain an option, more than half the states adopted "brittle" official search systems in which the searcher submits a name to the filing officer and the filing officer responds with a list of matches. ${ }^{118}$ By declaring financing statements ineffective if they would not be discovered in an official search under the debtor's correct name, using the filing office's standard search logic, the drafters of Article 9 made clear their intent. Searchers should search only in the exact, correct name of the debtor. ${ }^{119}$ That is what a reasonable searcher, searching in the Article 9 filing system, would do. Because the name used by the IRS in its tax lien filing against Spearing Tool was not one a reasonable searcher would find, the name

(Spearing Tool III), 412 F.3d 653, 656 (6th Cir. 2005).

116 Hudgins v. IRS (In re Hudgins), 967 F.2d 973, 977 (4th Cir. 1992) ("[I]n Norfolk County liens against individuals and liens against corporations were filed in the same index. In the Norfolk lien index at the time Hudgins filed for bankruptcy protection, there were only nine total listings under 'Hudgins,' all of them on the same page."); Reid v. IRS (In re Reid), 182 B.R. 443, 447 (Bankr. E.D. Va. 1995) ("On the computer terminal, both the correct and incorrect forms of the name appear on the same screen.").

117 See supra note 116.

118 For example, prior to revised Article 9, the Arizona Secretary of State maintained a flexible, on-line search system in which the user could enter only the root of a name and get a list of all consistent variations. Arizona U.C.C. Debtor or Secured Party Historical Search, http://www.azsos.gov/scripts/UCC_Search_PreRA9.cgi (last visited Jan. 27, 2007). Because that system arguably had no "standard search logic" as contemplated by U.C.C. $\S 9-506(\mathrm{c})$, the Secretary of State replaced it with an inflexible, on-line search system in which the user must enter the entire name and gets only a list of "matching" names. Arizona U.C.C. Lien Search, http://www.azsos.gov/scripts/ucc_search.dll (last visited Jan. 27, 2007).

${ }^{119}$ Harry Sigman, a member of the drafting committee, wrote:

[Revised Article 9] does not burden searchers with the obligation to dream up every potential error and name variation and perform searches under all possibilities. Revised Article 9 allows a searcher to rely on a single search conducted under the correct name of the debtor and penalizes filers only for errors that result in the nondisclosure of the financing statement in a search under the correct name.

Sigman, supra note 21 , at 73 ; see also, Ricotta \& Walker, supra note 1, at 26 ("RA9 generally provides that a searcher need only look under the correct legal name of a registered organization in order to determine if any prior U.C.C. liens have been perfected."). 
failed to identify the taxpayer in accord with federal law. That is what the district court held in Spearing Tool. ${ }^{120}$ To put it another way, one does not "identify" a taxpayer by filing in a name that searchers cannot connect with the taxpayer any more than one could identify a taxpayer by speaking the taxpayer's name in Chinese to listeners who understood only English.

The Sixth Circuit protested that "to subject the federal government to different identification requirements-varying with each state's electronic-search technology-'would run counter to the principle of uniformity which has long been the accepted practice in the field of federal taxation." "121 To invoke "uniformity" as the excuse for non-compliance with a debtor name standard agreed to by all fifty states, however, is beyond wrong to the point of ironic.

The court's reference is apparently to the fact that not every state applies the same search logic. That fact is irrelevant to the IRS's filing task. Had the Sixth Circuit invalidated the IRS's tax lien filings in Spearing Tool as seriously misleading, the IRS's task in future cases would have been to discover the exact, correct name of each corporate taxpayer and file in that name. A notice of tax lien bearing the exact, correct name would have been effective in every state. The IRS would have had no reason to discover and try to game the search logics of the various states. ${ }^{122}$ Functionally, the filing systems of every state would have presented the IRS with exactly the same debtor-name problem.

\section{Who COULD FIX THE SPEARING TOOL PROBLEM?}

\section{A. The Unlikelihood of Incremental Reform}

True commercial law disasters are rarely simple. If they were, the parties involved would simply agree to fix them. The Spearing Tool filing system disaster is, however, sufficiently complex that it will take on a life of its own. Although any of several participants in the filing system could fix it, none is

${ }^{120}$ In re Spearing Tool and Mfg. Co., Inc., (Spearing Tool II), 302 B.R. 351, 356-57 (E.D. Mich. 2003) ("It is not reasonable for searchers to conduct one search for liens that might include federal tax liens, and require them to conduct separate, multiple searches under the debtor's multiple possible names for a possible federal tax lien.").

121 United States v. Crestmark Bank (In re Spearing Tool and Mfg. Co., Inc.) (Spearing Tool III), 412 F.3d 653, 657 (6th Cir. 2005).

122 To test this proposition, ask yourself whether there is any policy or instruction the IRS might adopt or give its agents regarding the name to put on a notice of tax lien that might profitably vary depending on the state in which the filing was to be made. I can think of none. In all states the correct instruction would be to discover the exact, correct name from the state's website, file in that name, and be very careful in doing so. 
likely to do so.

The Sixth Circuit could reverse itself in another case. Other state or federal courts could express contrary views. Neither, however, is likely to happen. Courts could adopt views contrary to Spearing Tool only in cases to which the IRS is a party. The IRS manages its litigation in a manner that almost certainly will prevent this issue from arising again at the courts of appeal level. Specifically, the IRS settles, postpones, or dismisses cases systematically to assure that precedent favorable to the IRS is not threatened. ${ }^{123}$ Other litigants have no practical means of forcing the issue. The IRS can simply concede any case that threatens to produce a contrary ruling at the circuit level until system elements shift in ways that eliminate the threat of Spearing Tool's reversal. ${ }^{124}$ Even if by some miracle another circuit did make a timely ruling contrary to Spearing Tool, the problem would not be solved. Until the conflict among circuits is resolved, searchers with large amounts of money at stake would still feel the necessity to search name variations in every jurisdiction. Certiorari to the Supreme Court is always a long shot, even with a conflict among circuits.

The IRS could solve the Spearing Tool problem by issuing a regulation requiring filing in the exact, correct name of the debtor or a name that would not be "seriously misleading" under state law. The effect would be to invalidate the IRS's own filings if those filings would not be discovered by a search in the exact, correct name. Were the IRS at all inclined to do so, the IRS would not have litigated Spearing Tool all the way to the Sixth Circuit.

Congress could solve the problem by changing the law to authorize the states to impose on the IRS the debtor identification requirements of the filing systems in which the states require that tax liens be filed. The IRS would likely oppose that legislation, and be successful in defeating it.

Filing officers could expand their search logics to take account of IRS filing practices. For example, they could program their computers to return all 288 abbreviated variations on a search for "ABCD Christian Brothers Construction and Development Company of Michigan, Inc."125 Given the slow progress of the filing offices on far more basic problems-such as the usability of their web interfaces and the development of point-and-click filing-such programming is only a distant possibility. Nor could such programming ever return the system to the pre-Spearing Tool condition where searchers could search in the exact, correct name and be confident they had found all effective filings. The IRS could always make new kinds of errors and the courts could always find that a "reasonable search" would have overcome

123 See LoPucki \& Weyrauch, supra note 98, at 1451 (describing the "case selection strategy" generally).

124 See supra text accompanying note 111 (discussing such a shift).

125 Spearing Tool III, 412 F.3d 653, 656 (6th Cir. 2005). 
those errors.

Perhaps the most intriguing possibility for reform would be for filing officers to begin rejecting IRS filings that purport to be against domestic corporations but do not contain the correct spelling of the name of any domestic corporation. The IRS might welcome such a practice because it would bring some number of fatal errors to the IRS's attention and give the IRS the opportunity to cure them. But there is little incentive for a filing officer to risk the possibility of a hostile IRS reaction-or to spend the filing office's scarce resources fixing filing errors made by the IRS or other careless filers.

Considering all of these possibilities, there is little chance that any of these parties or techniques alone can solve the Spearing Tool problem. Once the Sixth Circuit's opinion became final, the problem took on a life of its own.

\section{B. A Proposal for Coordinated Reform}

To completely eliminate registered entity debtor-name-errors from the Article 9 and notice of federal tax lien filing system, four coordinated changes are necessary. ${ }^{126}$

First, each state would have to provide an internet-based point-and-click option for U.C.C. filing and searching against all entities registered in the state. To assist a user in finding the corporate record of its debtor, the system must provide an effective search of the corporate records by debtor name and perhaps other fields. To assist a user in establishing that the record found is in fact that of its debtor, the system should display the corporate information most likely to be of use in that regard, such as the names of officers and directors and associated addresses. That information should be visible on the computer screen at the time the selection is made. To assure that the debtor's name cannot be different in U.C.C. and corporate records, the same data field must be used as the debtor's name in both.

Second, each state would have to designate the debtor's name field used in the index of the internet-based system, not the name on the articles of incorporation, to be the exact, correct name of the debtor for purposes of filing and searching. Without that change, filings and searches would be ineffective whenever the corporate name in the debtor index differed from the corporate name on the articles of incorporation. The change degrades system function not at all, because in a point-and-click system no one can reasonably rely on articles of incorporation separate from the record on which the person points and clicks. In addition, the name on the articles may have been changed by

126 In addition, it would be helpful if the states that keep tax liens separate from Article 9 filings changed their practices. But the system could accomplish its goal of name-error-free filing and searching in other states without the cooperation of those states. 
amendment contained in the state's records.

Third, Congress would have to amend 26 U.S.C. $\S 6323(\mathrm{f})(2)$ to require that notices of tax liens against personal property be filed in the taxpayer's state of incorporation rather than at the taxpayer's principal executive office. (Tax liens against real property would continue to be filed where the property is located).

Fourth, the IRS and other filers would have to elect to use the electronic point-and-click filing system. IRS regulations already permit the IRS to do so. ${ }^{127}$

This reform would provide substantial benefits to the IRS. First, Spearing Tool forgave only the IRS filing errors that a reasonably diligent search would overcome, leaving it possible for the IRS to make more serious errors that invalidate their filings. This reform would solve the IRS's problem by completely eliminating name errors from IRS filings. Second, the uncertainty of the reasonably diligent search test invites litigation over name errors and so puts the IRS in potential conflict with lending institutions. By eliminating name errors, the reform would eliminate both the litigation and conflict. Third, by making the exact, correct names of corporations available to the IRS, the reform would give the IRS the ability to match Article 9 filings, Form 1099s, and other documents by exact, correct name when tax identification numbers were incorrect or unavailable.

The reform would have no significant adverse effect on the IRS. The IRS would have to file tax liens in taxpayers' exact, correct names, not the names furnished by the taxpayer. But, aside from the problematic flexibility afforded the IRS by the reasonably diligent search test, that is already the law. Nor would discovery of the exact, correct name be a significant burden. Even under Spearing Tool, the IRS should be checking corporate taxpayers' exact, correct names before filing. Nor would the changes require massive retraining of IRS personnel nationwide. In 2005, the IRS centralized its lien processing at the Cincinnati IRS Campus. ${ }^{128}$

Spearing Tool probably provided a windfall to the IRS. Crestmark's

12726 C.F.R. $\$ 301.6323(f)-1(d)$ (2006). That section provides:

The notice ... shall be filed on Form 668, "Notice of Federal Tax Lien Under Internal Revenue Laws". . . . The term "Form 668 " generally means a paper form. However, if a state in which a notice ... permits a notice of Federal tax lien to be filed by the use of an electronic or magnetic medium, the term "Form 668" includes a Form 668 filed by the use of any electronic or magnetic medium permitted by that state.

Id.

128 I.R.S., Centralized Lien Processing Guidelines for Recording Offices 3 (2006), available at http://www.pria.us/IRS/IRSGuidelinesCLPRecordersHandbook2006.doc (last visited Jan. 27, 2007). 
advances after the filing of the notice of tax lien augmented the debtor's assets and the court gave the IRS priority in those assets. But, as the Spearing Tool cases illustrate, such windfalls are not free. The IRS tends to incur litigation costs. Moreover, it is far from clear that it is in the long-run interest of the IRS to seek windfalls that come at even greater expense to taxpayers. That greater expense to taxpayers comes in the form of banks' loan advances lost to the IRS, litigation costs incurred in losing them, and increased filing and search costs incurred in the archaic filing system that generates the windfalls.

\section{CONCLUSION}

A key insight from systems analysis is that the right solution to a particular problem may depend on the solutions chosen for related problems. System change sometimes requires coordination. The debtor-name-error elimination project made two coordinated changes in the filing system. U.C.C. section 9-503(a)(1) required that filings be in the exact, correct name of the debtor so that searchers would have to search only in the exact, correct name. At the same time, U.C.C. sections 9-301 and 9-307(e) migrated corporate filings to the state of incorporation so that exact, correct names could be made easily available at the moment of filing or searching. Those changes provided the legal foundation for eliminating the debtor-name-error problem.

As the project neared success, the Sixth Circuit's decision in Spearing Tool destroyed that foundation by ruling that the IRS need not file its notices of tax liens in taxpayers' exact, correct names. That meant searchers who searched in the exact, correct names of their debtors could no longer be sure their searches discovered all effective filings. After Spearing Tool, Article 9 filing system searchers can find all effective filings only by searching at least some incorrect names-with no way to know for sure which incorrect names. The effect is to leave filers and searchers trapped in a twentieth-century filing system, continuing to waste resources on a problem technology has already solved, because a single court rejected that technology at the critical moment.

The court in Spearing Tool realized it was dealing with a real-world, law-related system and that the court's decision would affect how well that system would work. The court nevertheless reached the wrong result, apparently because it knew no method by which it could analyze the system. The method I present here-a form of systems analysis-fills the gap by demonstrating the falsity of the court's conclusion that the IRS had a substantial interest in being able to file against corporate taxpayers in incorrect names.

Spearing Tool struck what may prove to be a fatal blow to the debtor-name-error elimination project. Resuscitation may now be accomplished only through the unlikely mechanism of coordinated state and federal legislation. Such coordination is a formidable task in an age in which 
the legislative process is responsive principally to lobbying and campaign contributions rather than to the need for systemic improvements that benefit society as a whole. 
